Chris Procter // Education in a Changing Environment. 13th-14th September 2004. - University of Salford, Salford, Education Development Unit. - 2004. - 11 p. - Mode of access : http: //www.ece.salford.ac.uk/proeedings/papers/ah_04.rtf.

Інна Пащенко

\title{
АНАЛІЗ СТАНУ СФОРМОВАНОСТІ НАЦІОНАЛЬНОГО СВІТОГЛЯДУ МАЙБУТНІХ УЧИТЕЛІВ МУЗИКИ
}

Пащенко I. М. Аналіз стану сформованості національного світогляду майбутніх учителів музики.

У статті представлено результати стану сформованості національного світогляду майбутніх учителів музики. Проаналізовано критерії, показники сформованості національного світогляду i виявлено рівні його сформованості у межах констатувального експерименту.

Ключові слова: національний світогляд, майбутні вчителі музики, мотиваційний, когнітивно-аксіологічний, діяльнісно-праксеологічний критерії.

Пащенко И. Н. Анализ сформированности национального мировоззрения будущих учителей музыки.

В статье представлены результаты состояния сформированности национального мировоззрения будущих учителей музыки. Проанализированы критерии, показатели сформированности национального мировоззрения и выявлены уровни его сформированности в рамках констатирующего эксперимента.

Ключевые слова. Национальное мировоззрение, будущие учителя музыки,

Paschenko I. N. Analysis of the national ideology formation of future music teachers.

The article presents the cuttent results of national ideology formation of future music teachers. The criteria and indicators of the national ideology formation were analyzed and the levels of its formation in the framework of the ascertaining experiment were determined.

Key words: national ideology, future music teachers, motivational, cognitive-axiological, activity-praxeological criteria.

У роки утвердження незалежності України значними успіхами в розвитку національної педагогічної думки відроджується і визначається досвід національного виховання. Формування національної картини світу як упорядкованої системи уявлень, співвіднесених із певними культурними цінностями нації $€$ засадничим компонентом сучасної освіти в Україні. Національна ідентичність у своїй основі має духовні, культурні цінності, які виражаються через міфологію, філософію, мову, ідеологію, традиції, фольклор, мистецтво тощо.

Як відомо, формування національного світогляду майбутніх учителів музики є одним 3 актуальних завдань сучасної педагогічної освіти. На думку С. Борисової, «національний характер освіти, як пріоритетний напрямок її розвитку, було підкреслено в одному з останніх загальнодержавних документів - «Національній доктрині розвитку освіти», де зазначалося, що освіта має гуманістичний характер, грунтується на культурно-історичних цінностях 
українського народу, його традиціях і духовності; утверджує національну ідею, сприяє національній самоідентифікації, оволодінню цінностями світової культури та загальнолюдськими надбаннями» [1, с. 72]. Для реалізації усього комплексу професійних і виховних завдань, що ставляться нині перед учителями музики, важливе значення має сформованість їхнього національного світогляду.

Виявлення наявності і стійкості рис національного світогляду особистості, характеру світоглядної діяльності, неможливе без виявлення рівнів сформованості національного світогляду майбутніх учителів музики засобами фольклорно-етнографічного мистецтва відповідно до розроблених критеріїв та їх показників.

Вивченню проблем формування національного світогляду української молоді у процесі навчання та виховання присвячено праці філософів, психологів, педагогів-теоретиків і педагогів-практиків: М. Арцишевської, Р. Арцишевської, Р. Арцишевського, В. Безродної, К. Васильковської, О. Вишневського, Г. Гаєцької, О. Гончаренко, В. Горського, О. Гуцуляка, О. Дарморіз, В. Ільїна, А. Іваницького, В. Іванова, В. Капітонова, В. Кременя, О. Кульчицького, В. Максименко, А. Меграшвілі, Є. Носенко, Л. Побережної, Є. Роговської, О. Рудницької, М. Стельмаховича, А. Фрідріх, В. Шинкарука, В. Яніва, М. Ярової та ін.

Метою статті є визначення стану сформованості національного світогляду майбутніх учителів музики засобами фольклорно-етнографічного мистецтва, а завданнями уточнення критеріїв, показників і рівнів сформованості національного світогляду майбутніх учителів музики засобами фольклорно-етнографічного мистецтва на констатувальному етапі експериментального дослідження.

Задля визначення сучасного стану сформованості національного світогляду майбутніх учителів музики на основі використання фольклорно-етнографічного мистецтва було здійснено констатувальний експеримент, який передбачав послідовність, взаємопов'язаність і взаємозалежність чотирьох етапів дослідження, на кожному з яких розв'язувалися певні завдання, застосовувались педагогічні методи і прийоми:

1. Здійснити теоретичний аналіз існуючих у педагогічній освіті підходів і принципів формування національного світогляду майбутніх учителів, інноваційних методик i технологій, документації (освітні стандарти, навчальні та робочі програми 3 підготовки майбутніх учителів музики, зокрема з фольклорної та педагогічної практик, планів виховної роботи ВНЗ, завідувачів кафедр, кураторів, планів роботи кафедр) задля визначення ступеня наповненості їх змісту питаннями щодо завдань формування національного світогляду майбутнього вчителя музики засобами фольклорно-етнографічного мистецтва.

2. Визначити критерії, показники та рівні сформованості національного світогляду майбутнього вчителя музики засобами фольклорно-етнографічного мистецтва.

3. 3'ясувати сучасний стан розвитку світоглядного компонента професійної діяльності вчителів музики загальноосвітніх навчальних закладів за допомогою різних методів педагогічного спостереження.

4. Здійснити діагностування рівнів сформованості національного світогляду майбутніх учителів музики засобами фольклорно-етнографічного мистецтва відповідно до розроблених критеріїв та їх показників.

У педагогічному експерименті взяли участь 518 осіб, з-поміж яких 362 студенти, 56 учителів музичного мистецтва та 100 учнів загальноосвітніх навчальних закладів.

Усвідомлюючи етапність формування національного світогляду майбутніх учителів музики засобами фольклорно-етнографічного мистецтва, звертаємось до моделі виховного процесу формування особистості, розробленої С. Карпенчук. Науковець зазначає, що 
здійснення спілкування з фольклорно-етнографічним мистецтвом. Мотиваційний критерій виражає ступінь сформованості інтересу і мотивації майбутніх учителів музики в галузі застосування фольклорно-етнографічного мистецтва під час розв'язання світоглядних проблем професійної діяльності.

При цьому враховувалося, що формування національного світогляду майбутніх учителів музики засобами фольклорно-етнографічного мистецтва залежить від мотивації навчальної і творчої діяльності. Інтерес до самостійного освоєння і подальшого застосування світоглядного потенціалу українського фольклорно-етнографічного мистецтва в професійній діяльності майбутнього вчителя музики виражається в позитивному емоційному ставленні до української народної пісні, звичаїв, обрядів українського народу в цілому, до досконалості жанрової системи українського музичного фольклору, у прагненні до оволодіння виконавськими й аналітичними знаннями та вміннями, безперервному розвитку у сфері фольклорно-етнографічного мистецтва, що є необхідною умовою світоглядного становлення та розвитку. Моральна й естетична задоволеність результатами спілкування з музичним фольклором та етнографією є також важливою умовою розвитку інтересу до них і сприяє підвищенню активності студентів при вирішенні завдань світоглядного характеру.

Показниками мотиваційного критерію формування національного світогляду майбутніх учителів музики засобами фольклорно-етнографічного мистецтва є: ставлення до світоглядного змісту українського фольклорно-етнографічного мистецтва (розвиненість мотивів, пізнавальних інтересів); потреба у виробленні власної світоглядної позиції при спілкуванні з українським музичним фольклорно-етнографічним мистецтвом; прагнення до безперервного саморозвитку у напрямі світоглядного пізнання українського фольклорноетнографічного мистецтва.

Мотиваційний критерій сформованості національного світогляду засобами фольклорно-етнографічного мистецтва детермінує розвиток та активізацію когнітивноаксіологічного й діяльнісно-праксеологічного критеріїв. На думку Л. Потапюк, спонукальномотиваційний компонент допомагає здійснити зв'язок між духовним i практичним освоєнням дійсності; «спонукальну роль у різних світоглядах можуть відігравати певні глибинні почуття, світоглядні мотиви» [3, с. 9].

Аналіз джерел з проблеми дослідження вказує, що когнітивно-аксіологічний критерій $\epsilon$ ще одним необхідним критерієм формування національного світогляду особистості. Когнітивно-аксіологічний критерій формування національного світогляду майбутніх учителів музики засобами фольклорно-етнографічного мистецтва передбачає наявність у майбутнього вчителя музики знань фольклорно-етнографічного мистецтва та його національного світоглядного змісту, необхідних i достатніх для навчання учнів загальноосвітньої школи; здатність самостійно здобувати та розуміти інформацію про художньо-світоглядний зміст фольклорних цінностей; спрямованість на виявлення художньо-естетичного світогляду майбутнього вчителя музики та його досвіду спілкування з фольклорно-етнографічним мистецтвом.

Важливим видається зауваження Г. Сотської, «що організація процесу засвоєння студентами знань, набуття вмінь та навичок має поєднуватися з формуванням готовності до їх творчого застосування. За такої умови саме досвід творчої діяльності, втілений студентами в особливих інтелектуальних діях, дозволяє самостійно переносити в нову ситуацію раніше засвоєні знання і вміння; бачити нову функцію вже знайомого об’єкта; приймати альтернативи розв’язання проблеми та оригінальні засоби ії вирішення тощо» [4, с. 92-93]. Л. Потапюк наголошує, що процес формування цілісного світогляду заснований на 
поєднанні двох шляхів набуття знань - чуттєвого сприймання і розумової діяльності учнів [3, с. 12].

Когнітивно-аксіологічний критерій формування національного світогляду майбутніх учителів музики засобами фольклорно-етнографічного мистецтва базується на структуруванні необхідного обсягу теоретичних знань та ціннісних орієнтацій у кількох групах. Філософські та естетико-культурологічні знання охоплюють: знання про національний світогляд, його зміст та структуру, світоглядні уявлення особистості, що сягають цілісності, національну ідею та ії відображення у фольклорно-етнографічному мистецтві, наявність загальної мистецької ерудиції в галузі українського фольклорноетнографічного мистецтва. Психолого-педагогічні знання передбачають наявність: знань вікових та індивідуально-типологічних особливостей учнів різних класів та їх зв'язку 3 формуванням світоглядних уявлень, знань психолого-педагогічних основ застосування фольклорно-етнографічного мистецтва у процесі світоглядного розвитку учнів загальноосвітньої школи, вміння самостійно і переконливо аргументувати свою світоглядну позицію. До групи художньо-педагогічних знань студентів відносимо: знання про сутність, мету, завдання, роль національного українського фольклорно-етнографічного мистецтва у світоглядних засадах художньо-педагогічного процесу, знання про сучасні тенденції мистецької освіти, світоглядні, теоретичні та практичні засади українського фольклорноетнографічного мистецтва, естетичний світ творів українського музичного фольклору та його ідеальні художні вияви. До фахово-методичних належать знання: з методики впровадження елементів формування національного світогляду засобами українського фольклорноетнографічного мистецтва на уроках музики, гуртковій, факультативній роботі з учнями загальноосвітньої школи; щодо форм, методів і прийомів використання українського фольклорного-етнографічного мистецтва на уроках музики в загальноосвітній школі та орієнтованого на національні світоглядні традиції методичного подання ціннісного світу української народної музичної творчості.

Показниками когнітивно-аксіологічного критерію формування національного світогляду майбутніх учителів музики засобами фольклорно-етнографічного мистецтва постають: системність знань про національну картину світу та її складники; розуміння художньо-світоглядного змісту фольклорно-етнографічних цінностей українського народу та наявність особистісних оцінних ставлень до нього; знання про методику та практику використання світоглядного потенціалу українського фольклорно-етнографічного мистецтва у школі.

Діяльнісно-праксеологічний критерій формування національного світогляду передбачає сформованість умінь та навичок, творчого досвіду, особистісних і професійних якостей майбутніх учителів музики, що забезпечить їм в майбутньому успішне та ефективне навчання учнів загальноосвітнього навчального закладу, їхнє світоглядне виховання. Цей критерій допомагає перевірити схильність майбутніх учителів музики до пізнання своїх творчих виявів, досвід їхньої власної творчої діяльності; визначити ступінь володіння вміннями, що забезпечують яскраве виконання творчих завдань 3 демонстрацією сформованого комплексу навичок роботи з фольклорним матеріалом, відповідність виконавської діяльності студентів їхнім світоглядним уявленням; дозволяє з'ясувати ступінь самоактуалізації творчих можливостей особистості, спрямованих на формування готовності до виявлення національного світогляду у професійній діяльності. На думку Л. Потапюк, «якщо пізнавальна діяльність людини послідовна і повністю відповідає законам логіки, світогляд відзначається послідовністю і доказовістю, коли людина не може узагальнити 
знання, розуміння дійсності, законів її розвитку, то і не здатна брати участь у громадському житті» [3, с. 12].

Визначаючи рівень сформованості національного світогляду майбутніх учителів музики засобами фольклорно-етнографічного мистецтва, ми враховували всі названі вище критерії.

Високий (методологічний) рівень характеризується стійким позитивним ставленням до світоглядного змісту українського фольклорно-етнографічного мистецтва, розвиненістю мотивів та пізнавальних інтересів у цій галузі, сформованістю системних знань про національну картину світу та їі складники; повним розумінням художньо-світоглядного змісту фольклорно-етнографічних цінностей українського народу, володінням у великому обсязі знаннями про методику та практику використання світоглядного потенціалу українського фольклорно-етнографічного мистецтва у школі; високим ступенем розвиненості художньо-творчих спеціальних, педагогічних, методичних, комунікативних умінь відповідно до світоглядної зрілості особистості.

Середній (концептуальний) рівень визначається наявністю у студентів переважно позитивного ставлення до світоглядного змісту українського фольклорно-етнографічного мистецтва, що супроводжується розвиненістю мотивів щодо його пізнання, широких пізнавальних інтересів; обсягом та якістю теоретичної підготовки студентів, яка в цілому дозволяє їм розв'язувати світоглядні завдання, розуміти художньо-світоглядний зміст фольклорно-етнографічних цінностей українського народу, але 3 формальними особистісними оцінними судженнями; відносно високим ступенем розвиненості художньотворчих спеціальних, педагогічних, методичних, комунікативних умінь, який не дозволяє виявити у професійній діяльності світоглядну зрілість особистості.

Низький (методичний) рівень характеризується формальним ставленням до світоглядного змісту українського фольклорно-етнографічного мистецтва, недостатньою розвиненістю мотивів та пізнавальних інтересів; спрощеними, фрагментарними, несистемними знаннями про національну картину світу та їі зміст, однобічними особистісними оцінними судженнями про фольклорно-етнографічні цінності українського народу; невисоким ступенем розвиненості професійних умінь майбутніх учителів музики; невиразною спрямованістю фольклорної виконавської діяльності студентів до національних світоглядних уявлень, поглядів, ідеалів, переконань.

Під час третього етапу констатувального експерименту виявлено, що вчителі музичного мистецтва мають недостатній рівень підготовки до світоглядного навчання i виховання учнів засобами фольклорно-етнографічного мистецтва, зокрема до формування в них національного світогляду. Вважаємо позитивним, що вони усвідомлюють значення світоглядного навчання та виховання засобами фольклорно-етнографічного мистецтва на уроках музики, але є багато чинників, які заважать педагогічній і методичній організації цього процесу. Учителі-практики зазначають труднощів, пов’язаних передусім з недостатнім рівнем їхньої світоглядної основи професійної підготовки у вищих навчальних закладах.

Під час четвертого етапу експерименту для визначення рівня сформованості національного світогляду студентам I-V курсів було запропоновано анкети та тестові завдання, до яких було включено запитання на виявлення ставлення майбутніх учителів музики до світоглядного змісту українського фольклорно-етнографічного мистецтва, 3'ясування потреби майбутніх учителів музики у виробленні власної світоглядної позиції при спілкуванні з українським музичним фольклорно-етнографічним мистецтвом тощо.

Результати констатувального експерименту продемонстрували переважно низький 
рівень сформованості національного світогляду майбутніх учителів музики засобами фольклорно-етнографічного мистецтва за визначеними критеріями: за мотиваційним (13,8 \%), когнітивно-аксіологічним (60,8 \%), діяльнісно-праксеологічним $(60,2 \%)$, що загалом дало 45,0 \%. Це підтверджує неналежний стан вишівської підготовки студентівмузикантів до світоглядної діяльності та зумовило необхідність пошуку шляхів її вдосконалення.

Виявлено, що загальний рівень мотивації щодо сформованості системності знань про національну картину світу та їі складники в майбутніх учителів музики є низьким, знання студентів здебільшого неглибокі, нечіткі, несистематизовані. Майбутні вчителі не володіють методичними знаннями й уміннями організації фольклорно-етнографічної діяльності школярів. Потенційні можливості використання творів українського фольклорноетнографічного мистецтва у змісті переважної більшості навчальних дисциплін та виховній роботі педагогічного вишу залишаються практично нереалізованими.

Узагальнення результатів констатувального експерименту підтвердило необхідність цілеспрямованого формування національного світогляду майбутніх учителів музики.

Обов’язковим перспективним напрямом дослідження є розгляд методики формування національного світогляду майбутніх учителів музики засобами фольклорноетнографічного мистецтва.

\section{Література}

1. Борисова С. В. Формування національної самосвідомості майбутніх учителів засобами українського музичного мистецтва : дис. на здобуття наук. ступеня канд. пед. наук : 13.00.04 / Борисова Світлана Володимирівна. - Луганськ, 2002. - 186 с. 2. Карпенчук С. Г. Теорія і методика виховання: [навч. посіб. для студ. вищ. пед. навч. закл.]/ Світлана Григорівна Карпенчук. - Київ : Вища школа, 2005. - 343 с. З. Потапюк Л. М. Формування світогляду учнів підліткового та юнацького віку у навчально-виховному процесі сучасної школи: дис. на здобуття наук. ступеня канд. пед. наук : 13.00.07 / Потапюк Л. М. . Тернопіль, 2002. - 186 с. 4. Сотська Г. І. Підготовка майбутнього вчителя образотворчого мистецтва до навчання учнів основної школи художнього конструювання: дис. на здобуття наук. ступеня канд. пед. наук : 13.00.04 / Сотська Г. І. - K., 2008. - 210 с.

УДК 378

Лариса Рикова

\section{СИСТЕМНЕ ВИКОРИСТАННЯ МОДЕЛЕЙ У ВИКЛАДАННІ ПРИРОДНИЧО- МАТЕМАТИЧНИХ ДИСЦИПЛІН ЯК ОДИН 3 ЕФЕКТИВНИХ МЕТОДІВ ФУНДАМЕНТАЛІЗАЦІЇ ПІДГОТОВКИ МАЙБУТНІХ ПЕДАГОГІВ}

Рикова Л. Л. Системне використання моделей у викладанні природничоматематичних дисциплін як один 3 ефективних методів фундаменталізації підготовки майбутніх педагогів.

На основі аналізу сутності і функцій фундаменталізації освіти запропоновано три дидактичні умови використання моделей у викладанні природничо-математичних дисциплін задля реалізації основних принципів фундаменталізації підготовки майбутніх педагогів.

Ключові слова: фундаменталізація освіти, використання моделей, підготовка майбутніх педагогів.

Рыкова Л. Л. Системное использование моделей в преподавании естественно- 